\title{
Surveying a New Lincoln Survey
}

\section{GARY ERICKSON}

Describing his years at New Salem in the autobiography sent to John L. Scripps in 1860, Lincoln explained: "The Surveyor of Sangamon, offered a depute to A that portion of his work which was within his part of the county. He accepted, procured a compass and chain, studied Flint, and Gibson a little, and went at it. This procured bread and kept soul and body together."1 During the summer of 1833, John Calhoun, the Sangamon County Surveyor, offered Lincoln the deputy surveyor position for the northwestern part of Sangamon County in the surrounding area of New Salem, much of what would become Menard County in 1839. ${ }^{2}$ Accepting the challenge, Lincoln "went at it," with a manner similar to how he would later describe his self-taught course in law: " .. borrowed books of Stuart, took them home with him, and went at it in good earnest." On Lincoln's taking up surveying, Carl Sandburg commented, ". . . he had to transfer his blank ignorance of the science and art of surveying into a thorough working knowledge

1. “Autobiography written for John L. Scripps, June, 1860," Roy P. Basler et al., eds., The Collected Works of Abraham Lincoln, 9 vols. (New Brunswick, NJ: Rutgers University Press for the Abraham Lincoln Association, 1953), 4:65. (Hereinafter cited as CW.) Lincoln wrote this in preparation for Scripps's campaign biography to be published by the Chicago Press and Tribune. Using what Lincoln sent him, Scripps wrote, "Lincoln had no knowledge of surveying, or of the science on which it is based; but he was now too much absorbed by a desire for improvement to decline a position which, while securing a livelihood, would enable him to increase his acquirements. He accepted the kind proffer of Mr. Calhoun, contrived to procure a compass and chain, set himself down to the study of Flint and Gibson, and in a very short time took the field as a surveyor." In Roy P. Basler and Lloyd A. Dunlap, eds., John L. Scripps, Life of Abraham Lincoln (1860; Bloomington: Indiana University Press, 1961), 66.

2. John Calhoun's commission as surveyor of Sangamon County is dated Mar. 2, 1833. The date of his later appointment of Lincoln as deputy surveyor is not known. Most likely it was made in the spring of 1833, with Lincoln taking about three months for preparation to become a surveyor. Earl Schenck Miers, editor-in-chief, Lincoln Day By Day, A Chronology 1809-1865, 3 vols. (Washington: Lincoln Sesquicentennial Commission, 1960), 1:32. (Hereinafter cited as Day by Day.) Adin Baber, A. Lincoln with Compass and Chain (Kansas, Illinois: privately printed by the author, 1967), 9. (Hereinafter cited as Baber, Compass and Chain.) 
and skill." ${ }^{3}$ Land needed surveying and Lincoln needed an income. With the large influx of people emigrating into the prairies of central Illinois, there was a demand for surveyors to re-survey, for legal ownership, previously purchased federal lands in order to record legal land ownership and to settle boundary disagreements. Along with the growing support for internal improvements, new roads needed to be marked and mapped. As a result, Lincoln frequently endorsed petitions requesting the legislature to create a road. This increase in population and roads spawned land speculators eager to have new towns surveyed and divided into lots. ${ }^{4}$

Continuing into the fall of 1833 with his self-tutored course in surveying, and honing his skills by doing trial field work, Lincoln "went at it," accomplishing his first known survey for Reason Shipley on January 6, 1834. Between 1834 and 1836, Lincoln surveyed farmland, new roads, school sections, and five new town sites. A large percentage of his surveys was accomplished for farmers desiring clear land boundaries and titles. There are about a dozen known existing individual farm surveys in Lincoln's hand. These individual surveys were often recorded in the public record, but the actual survey papers were held by the landowner. Considering the need for land surveys, along with the number of surveys Lincoln must have completed to have "procured bread," many of these surveys have been lost or destroyed, or perhaps a few still are buried among family papers. The surveys for Reason Shipley and John Kennedy Kincaid and his brother, Archibald, were long held within their families. ${ }^{5}$ In retaining

3. CW, 4: 65. Carl Sandburg, Abraham Lincoln: The Prairie Years, 2 vols. (New York: Harcourt, Brace and Co., 1926), 1:169.

4. Lincoln followed the mainline Whig platform in being a strong advocate for internal improvements. A good summary of the influence of surveying upon Lincoln is in Kenneth J. Winkle, The Young Eagle: The Rise of Abraham Lincoln (Dallas: Taylor Trade, 2001), 113-14. For examples of Lincoln's road petitions see "Petition to County Commissioners" (Feb. 25, 1834); "To the County Commissioners' Court" (June 2, 1834, and Nov. 4, 1834); “Notice to Illinois Legislature of a Bill to Authorize Samuel Musick to Build a Toll Bridge" (Dec. 9, 1834). CW, 1:21, 24, 26, 28.

5. Baber, Compass and Chain, 39-46, 112; Day by Day, 1:36-64. Three of Lincoln's surveys, for Reason Shipley, Jesse Gum, and John K. Kincaid, were passed from one generation to the next. At the time of $\mathrm{CW}$, the Shipley survey was owned by Mrs. Herman G. Wilms; the Gum survey, March 3, 1834, was owned by Henry E. Beekman; and the Kincaid survey, March 24, 1835, was in the possession of a descendant, J. Kennedy Kincaid, residing near Athens, Illinois. CW, 1:20, 22-23, 37. The Gum survey was sold at a Sotheby's auction in 1987. The Kincaid survey was donated on December 10, 2005, by descendants, to the Abraham Lincoln Presidential Library \& Museum in Springfield. Merry Ann Malcolm, "Lincoln / J.K. Kincaid Survey" (privately printed paper, 2005), $1-2$. "Early Sangamon County surveying records are most fragmentary, so it is impos- 


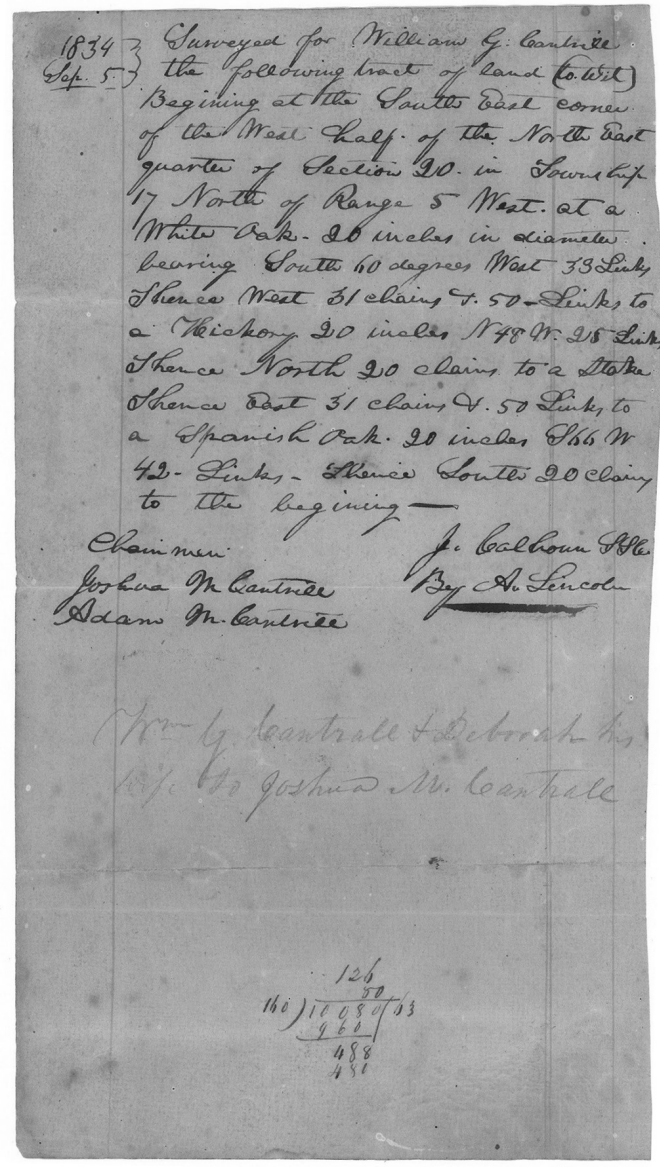

Figure 1. Original survey in Lincoln's hand for William G. Cantrill, Sept. 5, 1834

these survey documents, these families forever have connected their ancestors to this sparsely known period in Lincoln's life and profession as a surveyor.

Passed along through various family members, a previously unpublished Lincoln survey for an early Sangamon County settler has been uncovered and recently recorded electronically in the Papers of Abraham Lincoln. Accomplished nine months after the first known survey, it was for a farm parcel belonging to William Graham Cantrill, surveyed on September 5, 1834. The document was completely drawn up in Lincoln's hand and signed with his characteristic signature

sible to compile a complete listing of Lincoln's surveys ... Doubtless, ... he made many others." Harry E. Pratt, The Personal Finances of Abraham Lincoln (Springfield, Ill.: The Abraham Lincoln Association, 1943), 18. 
'A. Lincoln.' This survey was for a small tract of land, only 63 acres, in Section 20 of Township 17 [Fancy Creek] North, Range 5 West. It is northwest of Springfield about eight miles. Lincoln further documented it with 'J. Calhoun SSC' [Surveyor Sangamon County] and listed the chainmen who assisted him, Joshua M. Cantrill and Adam M. Cantrill, who were two of William G. Cantrill's sons. ${ }^{6}$

\section{Lincoln and "the Measure of Land"}

On the frontier, land ownership was equated with wealth. In a time of bank and currency uncertainty, land was considered "real money," as expressed by Jefferson, even though as secretary of State under Washington he had helped to create the money system for the United States. 7 Through his brief years as a surveyor, Lincoln also learned the value in titled-land holdings. Incorrect and conflicting surveys came at a risk that Lincoln knew firsthand. Three times his father, Thomas Lincoln, had been the victim of assumed farmland ownership that resulted in unclear titles with inaccurate surveys, a common problem in Kentucky that caused a mass migration into the Old Northwest for secure land titles. To what extent was Lincoln aware of his father's land struggles? Certainly enough to recall them in his autobiographical sketch to Scripps, where he remarked that his father left Kentucky "partly on account of slavery; but chiefly on account of the difficulty of land titles in Ky." Family discussions around it may have spawned Lincoln's interest in surveying. ${ }^{8}$

6. Certificate of Survey for William G. Cantrill, September 5, 1834.

https:/ / papersofabrahamlincoln.org/documents/D302441, The Papers of Abraham Lincoln Digital Library; Springfield, Illinois. This survey is not recorded in Baber's book, and is privately owned. The Cantrall family name has three spellings: Cantrill, Cantrell, and Cantrall. Even the brothers with the same parentage used all three spellings, depending upon personal preference. William's father, Joshua, used the French spelling, "Cantrell," and William took on the spelling "Cantrill" as it appeared on the survey. He used this spelling until around the mid-1840s when he changed to the spelling used by his brothers, "Cantrall." Therefore, "Cantrall" is used in this article unless direct reference is made to the survey or legal papers containing the "Cantrill" spelling.

7. Julian P. Boyd, ed., Papers of Thomas Jefferson (Princeton, N.J.: Princeton University Press, 1950), 1:99.

8. Olivier Frayssé (translated from the French by Sylvia Neely), Lincoln, Land, and Labor (Urbana and Chicago: University of Illinois Press, 1994), 8-12. This book offers an excellent account of Thomas Lincoln's issues with land titles as well as for the early settlers in Kentucky. CW, 4:61-62. Winkle, The Young Eagle, 10-12. R. Gerald McMurtry, The Kentucky Lincolns on Mill Creek (Harrogate, Tenn.: Department of Lincolniana, Lincoln Memorial University, 1939) is an early work on Thomas Lincoln's land transactions in the Mill Creek country of Kentucky. 
Having been nurtured in an agrarian society, Lincoln had a natural appeal for land. Though he had no desire to work the land as his father had labored for a living, Lincoln did know the value of land as a mark of success. Seeking self-advancement, he left the frontier farm of his father for the frontier community of New Salem. Lured by motivation, self-described as "ambition," Lincoln sought to shape his own destiny away from that "predestined" by his father. As a surveyor, he was not only mapping land in chains and links, he was mapping his self-improvement toward the Whig agenda for internal improvements. With his surveying skills, he helped to bring fertile lands into production, tamed disputed land with decisive surveys, ran roads across the wilderness, and created new towns for progressive speculators. Lincoln who had taken up an axe to split rails in Indiana and Illinois for farmers to mark fencing lines among neighboring farmers, now took up compass and chain to mark boundaries, often questionable boundaries as a result of no legal land titles. It had been an injustice he had experienced with his father in Kentucky. With becoming a surveyor, land was about to take on a larger role in Lincoln's life on the frontier.

First elected to the Illinois General Assembly on August 4, 1834, a month prior to the Cantrall survey, Lincoln was elected partly on a platform that stressed "the public utility of internal improvements" of the land to "the poorest and most thinly populated counties," bringing an end to rural isolation. ${ }^{9}$ New to the General Assembly, he worked aggressively on the passing of the equally aggressive Internal Improvement Act of 1837 . This $\$ 10$ million measure, along with the Panic of 1837, caused in part by President Jackson's monetary policy, cast on the people of Illinois a wall of debt. Two years later, to ease the stress of the debt, Lincoln proposed that Illinois should purchase 20 million acres of unappropriated federal lands within the state for 25 cents per acre, then resell it for the market price of $\$ 1.25$ per acre. This legislation included how such a purchase would generate enough revenue to pay off the original land purchase plus the interest on it, along with the debt on internal improvements. One of the resolutions in the bill, written by Lincoln, contained his surveying knowledge and experience: ". . . the said government of the United States, shall deliver over to the authorities of the said State of Illinois, all plats, field notes ... pertaining to the surveys of said lands." From firsthand

9. CW, 1:5-9. Lincoln related his self-described "ambition" to the Whig platform for internal improvements in his earliest surviving political statement, "Communication to the People of Sangamo County," March 9, 1832. 
experience, he understood the value of these plats and notes in the selling and the re-surveying of these held lands. The bill passed the General Assembly, but Congress failed to take it up. ${ }^{10}$

Land was also an aspect of Lincoln's legal work. In 1835, the year after the Cantrall survey, the Springfield Land Office led the ten state offices in land sales with 478,976 acres sold. Amid this rapid buying and selling of land, there arose disagreements over land rights and boundaries. Many of these disputes were settled out of court, but in 1837 the newly licensed lawyer Lincoln was retained to settle a dispute over land he had surveyed for David Hart in November 1834, two months after this Cantrall survey. Following Hart's death, Lincoln was retained to write a bill in chancery and petition for summons in Houghton v. heirs of David Hart. In writing this disposition on September 2, 1837, Lincoln stated that he had surveyed the 12.48 acres in question for Hart and understood Hart would have transferred it to Elijah Houghton. In June 1838, Judge Samuel Treat awarded the land to Houghton. The following year, in July 1839, the court appointed Lincoln to survey 17 acres of disputed land in Sangamon County in Butler v. Tilford et al. Completing this survey in August and reporting to the court at the November term, Lincoln probably made his last field survey with this case. Near the end of his law practice, he applied his earlier surveying experience in a request for an opinion on the meaning of the federal law of February 11, 1805, concerning the division of sections into quarters. Reflecting upon both surveying and this law, Lincoln concluded in his January 6, 1859, "Opinion Concerning Land Surveys" with these words: "Nearly, perhaps quite, all the original surveys are to some extent, erroneous, and, in some of the Sections, greatly so. In each of the latter, it is obvious that a more equitable mode of division than the above, might be adopted, but as error is infinitely various, perhaps no better single rule can be prescribed."11 It serves as a good reflection of Lincoln's legal thoughts on the "art of surveying" lands with possible "arbitrary boundaries."

10. Ronald C. White, Jr., A. Lincoln: A Biography (New York: Random House, 2009), 72-74. CW, 1:135-38. A separate printing of this bill is listed in Jay Monaghan, Lincoln Bibliography 1839-1939, 2 vols. (Springfield: Illinois State Historical Library, 1943-45), 1:1. Listed as Monaghan No. 1, it is titled "Ill. Legis. H.R. 11th Assem. Public Lands in Illinois. January $17,1839 \ldots$...

11.James Davis, Frontier Illinois (Bloomington: Indiana University Press, 1998), 207. Day By Day, 1:13. Lincoln was licensed to practice law on Sept. 9, 1836. Day By Day, 1:59. Baber, Compass and Chain, 93, 141. Survey for Sangamon County Circuit Court [Aug. 26, 1839], https:/ / papersofabrahamlincoln.org/documents/4008375. The Papers of Abraham Lincoln Digital Library. Lincoln Legal Briefs: A Quarterly Newsletter of the Lincoln Legal Papers (July-September 2007), no. 83. CW, 4:348. 
Land was central to Lincoln's development, from working with his own hands the land of his father, to splitting rails with the strength of his own arms, to surveying land with the precision of instruments, to practicing law as legislator and lawyer often with its ties to the land. For Lincoln, land opened the way for economic progress and agrarian development that would impact the slavery question for free land and free labor to promote the American Dream of self-improvement and advancement. New Salem served as a classroom for the evolving Lincoln, breaking with manual labor and discovering intellectual improvement through work as a storekeeper, a surveyor, and a lawyer. In the open classroom of New Salem, surveying was a course, not a career, that Lincoln engaged himself in for three years. Reading "Gibson a little" as his textbook, Lincoln likely read the opening sentence of the preface: "The word geometry imports no more than to measure the earth, or to measure land." The "measure of land" would always remain a part of his professional life. The logical exactitude of Lincoln's thought owes much to his study of mathematics beginning with Gibson's basics of Euclid's plane geometry enough to be a competent surveyor, and later, while riding the circuit, furthering his fascination with geometry in reading and nearly mastering the first six books of Euclid. ${ }^{12}$

\section{Surveying "Procured Bread"}

In the 1830s the strong migration into central Illinois was matched with an active buying and selling of land along with land speculation and mortgage foreclosures often involving less than ethical transactions. There was sufficient work for a surveyor, and Lincoln "went at it" as it "procured bread and kept soul and body together." As deputy surveyor, Lincoln was called upon to relocate boundaries established

12. Michael Burlingame, Abraham Lincoln: A Life, 2 vols. (Baltimore: Johns Hopkins University Press, 2008), 1:62-67; "Mentor Graham claimed that he taught Lincoln surveying, but that is highly unlikely, for Graham knew little math." 79. One of the first authors to label New Salem as Lincoln's classroom/college was William E. Barton in his chapter "Lincoln's Alma Mater, 1831-1837," in Barton, The Life of Abraham Lincoln, 2 vols. (Indianapolis: Bobbs-Merrill Co., 1925), 1:192-201. Frayssé, Lincoln, Land, and Labor, 58-61. CW, 4:65, and "Address Before the Wisconsin State Agricultural Society, Milwaukee, Wisconsin, Sept. 30, 1859," 3:471-82. Gabor Boritt, Lincoln and the Economics of the American Dream (Memphis: Memphis State University Press, 1978), 180-81. The textbook Lincoln read was Robert Gibson, The Theory and Practice of Surveying, which contained geometric elements from Euclid. Glenn W. LaFantasie, "Lincoln, Euclid, and the Satisfaction of Success," Journal of the Abraham Lincoln Association 41, no.1 (Winter 2020): 38-41. 
by the first surveyors for the U.S. Federal Land Office and to survey public lands for Sangamon County involving farm land often for migrants, town sites for speculators, new roads, or re-routing an existing road for improvement as authorized by the state legislature. On May 21, 1836, he certified his survey for the town of Huron, 12 miles northwest of New Salem, for speculators, in this case for some of "the old guard" of Springfield, among them John T. Stuart, Stephen T. Logan, Elijah Iles, Ninian W. Edwards, and Simeon Francis. For this survey Lincoln received a certain number of lots in Huron.

In accepting them for payment, he was speculating in Huron as a new town where two months earlier he already had purchased fortyseven acres near Huron on the Sangamon River for \$58.75. It was all to be a failed land speculation based upon the passage of a legislative bill which he had supported for building the Beardstown and Sangamon Canal. As was the case of many proposed canal projects at the time, it was never built. Perhaps Lincoln, caught up in the wave of speculation of 1836 Illinois, learned a lesson in mixing his surveying with speculating. As a surveyor Lincoln's income came from his public and private surveys rather than any land speculations. His reputation grew as an honest and skillful surveyor. Peter Van Bergen, a Springfield investor in laying out New Boston, recalled: "Mr. Lincoln was a good surveyor; he did it all himself, without help from anybody except chainmen ... " ${ }^{\prime 13}$ Lincoln's integrity as a surveyor was established early in his profession as recorded with his survey for Russell Godbey on January 14, 1834. Years later Godbey testified to Herndon: "He surveyed

13. Frayssé, Lincoln, Land, and Labor, 74-75, is a good summary of Lincoln's thoughts and actions with land speculation around Huron. Baber, Compass and Chain, 129. Pratt, The Personal Finances of Abraham Lincoln, 58-59. Burlingame, Abraham Lincoln: A Life, 1: 80. Also, Van Bergen interview with John G. Nicolay, Springfield, July 7, 1875, in Michael Burlingame, ed., An Oral History of Abraham Lincoln: John G. Nicolay's Interviews and Essays (Carbondale and Edwardsville: Southern Illinois University Press, 1996), 33. This is the same Van Bergen who in April 1834 began one of the suits against Lincoln, Berry, and Green for nonpayment of a note in relation to the purchase of merchandise from Reuben Radford. Van Bergen along with other creditors won the judgment and to satisfy the debt, Lincoln's surveying tools and horse were sold by the sheriff. A New Salem neighbor, James Short, whom Lincoln had stayed with, bought Lincoln's possessions for $\$ 120$ and returned them to him. However, Wayne Temple has written that "William Butler told John G. Nicolay on June 13, 1875, that he . . furnished the money to buy back Lincoln's horse and surveying instruments from Peter Van Bergen ... . a good deed usually credited to James Short of Sand Ridge Precinct." Wayne C. Temple, Lincoln's Springfield/Pittsfield Connection "A Tale of Two Cities," (Mahomet, Ill.: Mayhaven Pub., 2017), 39. Holding no grudges, Lincoln later worked with Van Bergen in surveying New Boston on September 30, 1834, about 100 miles northwest of New Salem in Mercer County. 
the first piece of land I ever had surveyed. He staid with me all night and Sold him two buck-skins well dressed to fox his surveyor's pants ... I voted for Lincoln in opposition to my own creed-[and] faith in Politics ... Voted for him in 1834."14

Lincoln's honest character and growing reputation as a surveyor were further sealed in settling a boundary dispute between Henry McHenry and his neighbors. Playing the dual role of surveyor and "lawyer," he was chosen by the parties, who agreed to abide by his decision. McHenry later described to Herndon that "he came down with compass-flag-staff-chain ... stopped with me 3 or 4 days and surveyed the whole section. When the disputed corner arrived at by actual survey, Lincoln then stuck down his staff and said'Gentlemen-here is the Corner.' We then went to work and dug down in the ground ... found about 6 or 8 inches of the original stake... and at the bottom a piece of charcoal put there by Rector-who surveyed the whole County." 15

As Lincoln "went at it," he used surveying to enhance self-improvement as well as using surveying to tame the land which advanced the Whig cause for internal improvements. Years later when Herndon wrote to Theodore Parker, the transcendentalist and abolitionist, Herndon became philosophical with self-impressions. Attempting to impress Parker, he wrote about the changing landscape north of Springfield: "I am now at the [Sangamon] river standing on a high bold knob where I stood twenty years ago; but, $\mathrm{O}$, what a change! Instead of wilderness and wolves, I see farm on farm till they melt on the horizon, and cattle and sheep scattered along the plain. The deep, owl-forest has been cut away, and the wood-man's axe kisses the sun in its whirl. $\mathrm{O}$, what a change-all for the better."16 For three years, Lincoln, with his compass, 66-foot chain, stakes, range poles, plumb bobs, and axe, adventured the prairies, woods, swamps, and weather to help bring about the "change" his future law partner would

14. Douglas L. Wilson and Rodney O. Davis, eds., Herndon's Informants (Urbana: University of Illinois Press, 1998), 449. Russell Godbey to Herndon [1865-66]. The connection between Squire Godbey's vote for Lincoln in the August 4, 1834, election for the Illinois General Assembly, and Lincoln's having surveyed land for him, is testimony to how his survey work made him known beyond the area of New Salem.

15. Wilson and Davis, Herndon's Informants, 14-15. Written less than two months after Lincoln's assassination and glorifying his surveying skills, the statement was written out by Herndon and signed by Henry McHenry, Petersburg, Illinois, May 29, 1865.

16. Joseph Fort Newton, Lincoln and Herndon (Cedar Rapids: The Torch Press, 1910), 103-106. William H. Herndon to "Friend Parker," Springfield, January 24, 1857. Herndon and Parker carried on a correspondence for five years, Parker even coming to Springfield. 
comment on 20 years later. In August 1835, Thomas M. Neale was elected county surveyor, replacing appointed John Calhoun. Lincoln continued as Neale's deputy surveyor. The following month, a "Surveyor's Notice" appeared in the Springfield newspaper: "I have appointed John B. Watson, Abram Lincoln, and John Calhoun Deputy Surveyor for Sangamon County. In my absence from town any persons wishing their land surveyed, will do well to call at the Recorder's office ... and their business shall be promptly attended to. Sept. 10, 1835. T. M. Neale."17 Lincoln's work as a surveyor was hard work, always dealing with the elements of nature, but it also acquainted him with the growing population of Sangamon County, including the Cantrall family.

\section{Lincoln and the Cantralls: "Too Good a Whig"}

In the small webbed community around the William G. Cantrall farm, southeast of New Salem and Athens, Lincoln was acquainted with the Cantralls. Campaigning for the Illinois General Assembly and being elected as a Whig a month prior to this Cantrall survey, Lincoln had support among the Cantralls, who were Whigs. This recently uncovered survey also uncovers some of the extended story between the Cantralls and Lincoln.

William G. Cantrall (1784-1867) and his wife, Deborah Mitts Cantrall (1785-1856), along with their ten children, journeyed from Huron County, Ohio, to Sangamon County, Illinois, arriving on November 1,1824 . They squatted on land near William's brother, Levi Cantrall, who had come to Sangamon County in 1819. A year later, on October 26, 1825, William and Deborah walked into the General Land Office in Springfield, (soon to be managed by Dr. John Todd, an uncle to Mary Todd), to purchase their claimed 80 acres of settled land. Located in

17. Benjamin P. Thomas, Lincoln's New Salem (Springfield: The Abraham Lincoln Association, 1934), 74. On August 3, 1835, in the first election for county surveyor, Lincoln's vote helped to elect Neale as county surveyor. (Neale ran against Reuben Harrison and Parnell Hamilton.) Neale was trained as both a surveyor and lawyer, was an early supporter of Henry Clay, and helped support Sangamon River transportation with the Talisman and, like Lincoln, fought in the Black Hawk War. He was elected county surveyor three times and held the office at his death on August 7, 1840. Paul M. Angle, "Here I Have Lived:" A History of Lincoln's Springfield, 1821-1865 (Springfield: The Abraham Lincoln Association, 1935), 31, 37, 39. The "Surveyor's Notice," Sangamo Journal, Sept. 12, 1835, p. 3, col. 4. Since John Calhoun was listed as a deputy surveyor, he may have possessed more surveying skills than is presented in various sources. According to Baber, Lincoln borrowed books from Calhoun to study surveying. Baber, Compass and Chain, 1. 
Congressional Township 17, the east half of the northwest quarter of Section 20, it would become a portion of the 63 acres surveyed by Lincoln. ${ }^{18}$ In politics both William and Levi Cantrall had Whig leanings; they knew and supported Lincoln in his election on August 4, 1834, to the General Assembly. Levi may have been a signer on a local petition (no longer in existence) "to view and relocate part of the road between Sangamotown and the town of Athens." The Sangamon County Commissioners' Court received the petition and passed the request on September 1, 1834. With Levi and his brother William owning land near the road, Levi was appointed as a witness to the road location. More pertinent, Abraham Lincoln was "appointed" to survey and map the road. Drafting the document, he signed it along with Levi Cantrall and James Strawbridge. Having self-interest in this road project, Levi may have assisted Lincoln with the survey. Lincoln submitted a bill for his work:

Herewith is the map-The court may allow me the following charges if they think proper-

$$
\begin{aligned}
& 1 \text { day's labor as surveyor- } \quad \$ 3.00 \\
& \text { Making maps- } \quad \quad .50 \\
& \$ 3.50 \text { A. Lincoln }
\end{aligned}
$$

The signed statement that Lincoln submitted to the Sangamon County Commissioners' Court read:

To the county commissioner's court for the county of SangamonWe the undersigned being appointed to view and relocate a part of the road between Sangamon town and the town of Athens, respectfully report that we have performed the duty of said appointment according to law-and that we have made the said

18. Carmi G. Cantrell, ed., The Cantrell Family: A Biographical Album and History of the Descendants of Zebulon Cantrell . . . (Springfield, Ill.: Illinois State Register Printing House, 1898), 50, 58. This work contains a genealogical history of the Cantrall family. The town of Cantrall was laid out on land owned by Levi and first called Antioch, later changed to Cantrall in memory of Levi. John Carroll Power, History of the Early Settlers, Sangamon County, Illinois, Centennial Record (Springfield, Ill.: Edwin A. Wilson and Co., 1876), 78-83. History of Sangamon County, Illinois [series: History of Illinois] (Chicago: Interstate Publishing Co., 1881), 897-98. Robert Mazrim, The Sangamo Frontier: History and Archaeology in the Shadow of Lincoln (Chicago: University of Chicago Press, 2007), 208-10. William G. purchased 80 acres on October 26, 1825, for $\$ 100$, described as E 1/2 NW 1/4 of Section 20, Township 17N, Range 5W, 3rd Meridian of Sangamon County, recorded in Vol. 68, p. 15, Illinois State Archives (Springfield); also recorded in Boyd, Family Maps of Sangamon County, Illinois, Map Group 6, 91. The public lands in Sangamon County were first surveyed in 1821, and the U.S. Land Office in Springfield was legally established in 1822. Davis, Frontier Illinois, 206. 
relocation on good ground, and believe the same to be necessary and proper.

Athens Nov. 4-1834-

James Strawbridge-

Levi Cantrall-

A. Lincoln-

Lincoln completed this road survey two months after making the William Cantrall survey; the Cantrall property was a couple of miles east of the southern edge of this road. ${ }^{19}$

Four years later, Levi Cantrall encountered Lincoln when Levi served on the jury for the sensational 1838 murder trial People v. Truett. Henry Truett held the lucrative political appointment as Register of the Galena Land Office. Truett charged Dr. Jacob Early, a Douglas ally, with requesting President Van Buren to dismiss Truett. On March 5, 1838, at Major Spottswood's Hotel, later known as the Globe Tavern, in Springfield, Truett accused Dr. Early of drafting resolutions adopted at the recent Democratic convention in Peoria disapproving of Truett's appointment as register and seeking his removal. The jury heard conflicting reports as to when Truett drew his pistol and when Early picked up a chair either as a weapon or as a defense. It resulted in Truett's firing his pistol either accidentally or intentionally at Early, who died three days later. The incident roused Springfield. Truett formed a strong defense by hiring some of the strongest legal minds in Springfield: Stuart, Logan, Baker, Edwards, and Lincoln, the last of whom had been in practice for about a year and a half. Of interest, Stephen Douglas was named the lead prosecutor. Jury selection began on October 9, 1838, with lawyers rejecting dozens of potential jurors before making a final selection, which included Levi Cantrall.

19. Ida M. Tarbell, assisted by J. McCan Davis, The Early Life of Abraham Lincoln: Containing Many Unpublished Documents and Unpublished Reminiscences of Lincoln's Early Friends (New York: S. S. McClure, 1896), 198-99. Baber, Compass and Chain, 90-91. (Baber drew Lincoln's map to show north at the top and to include present roads.) On December 1, the Sangamon County Commissioners' Court accepted the report and survey, ordered the road to be opened, and allowed Lincoln $\$ 3.50$ for his surveyor's work. State of Illinois: Sangamon County Commissioners' Court Record Book D, 1833-1840, June 3, 1834, 90-91, and Dec. 1, 1834, 101-102, Manuscripts Collection, Abraham Lincoln Presidential Library. "Lincoln's survey map depicts the section of road with Athens to the south and the boundary line of Township 17 North at the north end. That notation was an error, as Township 17 North is south of Athens, rather than north as Lincoln's map indicates. Lincoln's map actually shows the location of the road from Athens northward to the boundary line of Township 18 North, rather than 17 North." Report of James Strawbridge, Levi Cantrall, and Abraham Lincoln to the Sangamon County Commissioners' Court [Nov. 4, 1834]. https://papersofabrahamlincoln.org /documents/D200036. PAL Digital Library. 
The trial began on October 11th in the Sangamon Circuit Court on Hoffman's Row, which happened to be one floor below the law office of Stuart and Lincoln. Serving on the jury, Levi heard the conflicting evidence. Lincoln was selected to deliver the closing argument to the jury. Though there is no record of his "short but strong and sensible" presentation, it must have been convincing as Levi and the other jurors returned a verdict of not guilty. ${ }^{20}$

Lincoln's professional relationship with the extended Cantrall family is further revealed when Lincoln, as a money lender, extended a loan to Thomas Cantrall, Levi's oldest son, for $\$ 600$ on November 28,1851 for two years with interest at ten per cent, secured with 80 acres of farm land, near the Cantrall survey. On November 29, 1852, Thomas and his wife, Elizabeth, gave Lincoln a new note for $\$ 660$, releasing the first note. The new note, written and signed by Lincoln, contained on the reverse side three interest payments between 1854 and 1855. Then a tragic accident took Thomas's life when on June 22, 1856, while working at a sawmill, his team of horses became frightened at the blowing of the whistle, ran off, and dragged a log over him. A younger brother, Charles S. Cantrall, administered the estate, paid off the note where Lincoln recorded on it: "Received, June 22, 1858 of Charles S. Cantrall, adm. of Thomas Cantrall, eight hundred and

20. John J. Duff, A. Lincoln: Prairie Lawyer (New York: Rinehart and Co., 1960), 51-61. Burlingame, Abraham Lincoln: A Life, 1:132-33. Richard Lawrence Miller, Lincoln and His World: The Early Years, Birth to Illinois Legislator (Mechanicsburg, Pa.: Stackpole Books, 2012), 1: 228-31. Stuart and Lincoln were retained in Patterson et al. v. Casey et al., a case to sue the heirs of Green Casey to sell his land in Sangamon County to pay his debts. Levi Cantrall Sr. served as a surety and signer, October 1838. Martha L. Benner and Cullom Davis et al., eds., The Law Practice of Abraham Lincoln: Complete Documentary Edition, 2nd ed. (Springfield: Illinois Historic Preservation Agency, 2009), case file ID: L03020, at www.lawpracticeofabrahamlincoln.org. In 1853 Levi Cantrall retained Lincoln and Herndon to sell 247 acres owned by Levi's son Stephen, declared insane, appointing Levi as his conservator, until the sale of the land to pay Stephen's debts. Lincoln and Herndon received $\$ 25.00$ for their legal services. For several years Levi served as the conservator of Stephen, later retaining Herndon to have the court appoint another son, Charles, to serve as conservator for Stephen. Benner and Davis, eds., Law Practice of Abraham Lincoln, Case File ID: L03009 and L03660, Conservator of Cantrall v. Cantrall. Levi's will was contested by some of his sons, who retained Herndon to request the court to stop Levi's widow, Ann, from selling all the personal property at public auction. They claimed that Ann and son Joseph had induced Levi, who was "not of sound mind and body," to change his will. William G. Cantrall served as a witness in these proceedings. The parties made a settlement and the case was dismissed. Proceedings began on May 16, 1860, and Herndon received $\$ 10.00$ for his legal services. Benner and Davis, eds., Law Practice of Abraham Lincoln, Case File ID: L00372, Cantrall et al. $v$. Cantrall et al. (Levi Cantrall died, Feb. 20, 1860, at the age 72 and is buried in Canterbury Cemetery, Cantrall, Il.) 
twenty-four dollars and twenty-four cents, in full balance of principal and interest on the note." 21

Within five miles north of William Cantrall's farm was the neighboring homestead of George Power, a justice of the peace for Fancy Creek Precinct in Sangamon County from 1828 into the 1840s. Tradition holds that Lincoln practiced law before Justice Power in the small white frame building, that is today still on the grounds, known as the 'Power Court House'; that he presented his first case there, in 1836; and that he would spend the night there when unable to return to New Salem..$^{22}$ It is noteworthy that William succeeded George Power as justice of the peace, serving two terms. William's two commission papers were signed by Governor Thomas Ford on August 15, 1843, and August 5, 1847.23

An unusual relationship between William and Lincoln was their mutual association with Seth M. Tinsley. In 1837 William formed a curious business partnership with Tinsley, just one of Tinsley's several partnerships in the 1830s. Less than two years later the Sangamo Journal announced, on January 6, 1838, its dissolution, asking settlement of all claims. Later in the month, "Tinsley-Cantrall and Co." sued Thomas Johnson for an unpaid promissory note of $\$ 82.20$ in the J.P. Court of Macon County. Legal records in this case indicate that Stuart and Lincoln probably represented Tinsley and Cantrall. Seth M. Tinsley owned the building that housed the second Logan and Lincoln law office (ca. 1843-1844) and what became the first Lincoln and Herndon law office (ca. 1844-1852). Tinsley also owned a cottage at 214 South Fourth St. that he rented to Abraham and Mary Lincoln in 1843 when

21. Charles Hamilton, Catalogue No. 102, January 20, 1977, 45-46. A listing of "a promissory note from Thomas Cantrall to Abraham Lincoln, all in Lincoln's hand except for Cantrall's signature, Springfield, Nov. 29, 1852." The three interest payments on the reverse are dated Jan. 6, 1854, Feb. 9, 1855, and Dec. 19, 1855. Mortgage of Thomas and Elizabeth Cantrall to Abraham Lincoln, Nov. 29, 1852, Lincoln Collection, ALPL. Pratt, The Personal Finances of Abraham Lincoln, 75, 58-70. (Lincoln was more financially successful as a money lender than a land speculator.)

22. Louis Obed Renne, Lincoln and the Land of the Sangamon (Boston: Chapman and Grimes, 1945), 31. Ralph Gary, Following in Lincoln's Footsteps: A Complete Annotated Reference to Hundreds of Historical Sites Visited by Abraham Lincoln (New York: Carroll and Graf, 2001), 23. Harry Estill, Power Farms: The Story of George Power and the Illinois Farm He Developed (Springfield: Sangamon County Historical Society, 2011), 10-11. George Power (1798-1886) came to the region about the same time as the Cantralls in 1821. In 1828 he built a two-room frame house, the first frame building in the county north of the Sangamon River. Elected justice of the peace in 1828, Power held court in one of the rooms.

23. Sangamo Journal, August 6, 1847, p. 3, col. 3. "Cantrall Family Collection," Sangamon Valley Collection, Lincoln [Public] Library, Springfield, Ill., 90-23 Cantrall Collection. 
they left the Globe Tavern. And in 1844 Tinsley co-signed the receipt between the Rev. Charles Dresser and Lincoln for the only house ever owned by the Lincolns. ${ }^{24}$

William G. Cantrall's most influential public office was his election to the Sangamon County Commissioners' Court, where he served for three years, 1835-1837. Meeting quarterly, the commissioners' court had jurisdiction to manage county revenue, impose and regulate county taxes, grant licenses (such as for a tavern), and manage public roads, canals, turnpikes, ferries, and bridges. Some of Cantrall's time on the court was served with Thomas Moffett, a lawyer and colleague of Lincoln, and with Samuel Berry, a justice of the peace and an uncle of Lincoln's New Salem failed business partner, William F. Berry. The three years of Cantrall's service were critical years for Sangamon County, marked by the resolution for the relocation of the state capital from Vandalia to Springfield, legislation Lincoln had actively worked on in the State Assembly. At the commissioners' court, March Term of 1837, Cantrall along with two other commissioners signed the indenture to convey to Governor Duncan for the consideration of one dollar, the "parcel of ground . . . being in the town of Springfield ... known as the Public Square, and containing two and a half acres ... [where] shall be erected a State House ... " ${ }^{25}$ Serving as a court commissioner, Cantrall had several contacts with Lincoln including a few petitions for roads such as one at the March Term, a petition Lincoln wrote for George Miller for a road to be located from the Morgan County line near Watkin's Mill to Miller's Ferry toward Pekin. Lincoln, along with two others, was appointed to locate the road. ${ }^{26}$ Surveying

24. Sangamo Journal, January 6, 1838, p. 3, col. 3. The Law Practice of Abraham Lincoln, The Lincoln Papers, ALPL, Apr. 29, 1837, doc. 92509; Jan. 20, 1838, doc. 92510. (It is marked "unspecified" as to which party Stuart and Lincoln represented.) The Office Fee Book, no date or page, does list a fee of $\$ 10.00$. Office Fee Book (reproduction), ALPL. Wayne C. Temple, By Square and Compass: Saga of the Lincoln Home, rev. ed. (Mahomet, Ill.: Mayhaven Pub., 2002), 32.

25. Daniel W. Stowell, ed., The Papers of Abraham Lincoln: Legal Documents and Cases, 4 vols. (Charlottesville: University of Virginia Press, 2008), 4:295-96. The clerk of the Sangamon County Commissioners' Court, Charles R. Matheny (1786-1839), because of his position, had frequent contact with Lincoln. He was the father of Lincoln's friend and best man at his wedding, James H. Matheny (1818-1890). Sunderine W. Temple and Wayne C. Temple, Illinois' Fifth Capitol: The House That Lincoln Built and Caused to be Rebuilt (1837-1865) (Springfield: Phillips Brothers, ptr., 1988), 78-79.

26. State of Illinois. Sangamon County Commissioners' Court Record, Book D, March $8,1836,189$. Manuscripts Collection, ALPL. Miers, Day by Day, 1:55. At the September 1836 term, Lincoln wrote and signed a petition asking the Commissioners' Court to relocate a road leading from Watkin's Mill via Miller's Ferry north toward Pekin. Miers, Day by Day, 1:59. 
helped Lincoln earn the trust of people who would continue to cross his calculated path for the next 25 years, and who, like the Cantralls, were leaders in the growing communities along the Sangamon River.

\section{“1834, Sept. 5, Surveyed for William G. Cantrill”}

When Lincoln surveyed the 63-acre parcel for William Cantrall in 1834, William owned about 440 acres in Sections 20 and 19 in Township 17 (Fancy Creek) in Sangamon County. Since his arrival ten years earlier in November 1824 and his first recorded purchase of 80 acres on October 26, 1825, William continued to acquire land, a sign of wealth. By the end of 1835, his land holdings in Sections 20 and 19 had expanded to over 600 acres, slightly less than a complete section (640 acres). All of the parcels forming his 600 acres, along with the two 40 -acre parcels purchased in 1833 and 1834 by his son, Joshua, were tangent to one another. ${ }^{27}$

In seeking a surveyor, William most likely approached John Calhoun, Lincoln's overseer and the designated surveyor for the county. Having "assigned" this northwestern region of Sangamon to Lincoln, Calhoun may have sent Lincoln to Cantrall. Or, having been aware of Lincoln as a candidate for the legislature and as a reputable surveyor, Cantrall on his own may have approached Lincoln to conduct this survey. He may have encountered him while surveying property for his neighbors or even for his brother Levi; if that is the case, those surveys are now lost to history. For Lincoln to have made surveying profitable, he had to have completed more surveys than are extant. Since a majority of Lincoln's surveys were completed to the west and northwest of the Cantrall farm, in what became Menard County, it is probable that Cantrall directly requested Lincoln to accomplish this comparatively simple survey. ${ }^{28}$

27. The plat shown nearby, "Land Owned by William G. Cantrall," details the locations and dates for his purchases in Sections 19 and 20. Most of these parcels were purchased from the federal lands except for two parcels of 80 acres each, purchased from a neighbor, Holsey Smith, on February 4, 1833. For a complete listing of William G. Cantrall's land holdings in Sections 19, 20, 21, and 16, see Boyd, Family Maps of Sangamon County, 91, 96. The author is indebted to Duane Weiss, surveyor and past president of the Illinois Professional Land Surveyors Association, for drawing the plat from information he received from the author's research.

28. A month prior to the Cantrall survey, Lincoln had been elected to the Illinois General Assembly. In 1839 Menard County was carved out of Sangamon County, placing a majority of his surveys into what is now Menard. His survey farthest east from New Salem and in some proximity to the Cantrall survey is the John Kincaid survey, March 24, 1835, along with a School Section 16 survey, May 10, 1836, both in Menard. James T. 


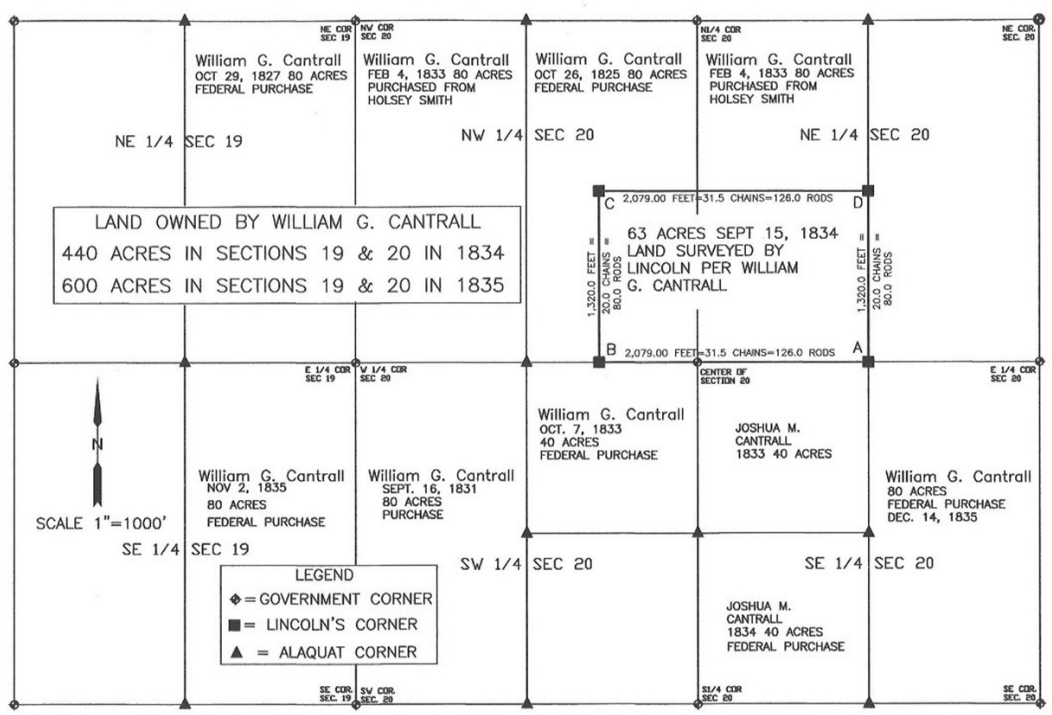

Figure 2. Land owned by William G. Cantrall in 1834-35 showing the 63 acres surveyed by Lincoln

There was an intended purpose for all of Lincoln's surveys. To speculate on the reason William Cantrall had Lincoln survey a rectangular 63-acre tract, "snuggled" near the center of his holdings, adds human interest to the narrative. This unusual number and location of acres may suggest that a residence or structure existed or needed to be bypassed on his land. Since he and his son, Joshua, owned all the land bordering the Lincoln survey, except for the eastern border, he was not surveying it for any boundary disagreements. The Cantralls possessed clear land titles. ${ }^{29}$ A very plausible reason for implementing this survey was the intent to pass on this land to his son Joshua,

Hickey's entries on Lincoln in Farm Plat Book Menard County, Illinois (Petersburg: Menard County Farm Bureau Bulletin, 1955), 29:6, given to the author by the late Betty Hickey.

29 . The two 80 -acre sections used by Lincoln to complete the requested survey were purchased by Cantrall and recorded: October 26, 1825, Recorded in Vol.68, p.15, Illinois State Archives, Springfield, Illinois, and February 4, 1833, Deeds Land Book F, p.271, Sangamon Valley Collection. A previously unknown Lincoln survey involving a land dispute was discovered in about 1990; "At the July 1836 term of Morgan County Court, Robert Davidson filed a bill of complaint against Isham Reavis for fraud and misrepresentation. Lincoln was hired by Davidson to survey two tracts of land and serve as a deponent in the suit." On Oct. 10, 1836, he surveyed a parcel of land for the plaintiff. See William D. Beard, "Procuring Bread: A New Lincoln Survey," The Lincoln Newsletter: A Publication of the Lincoln College Museum, 10:4 (Winter 1991), 4-5. 


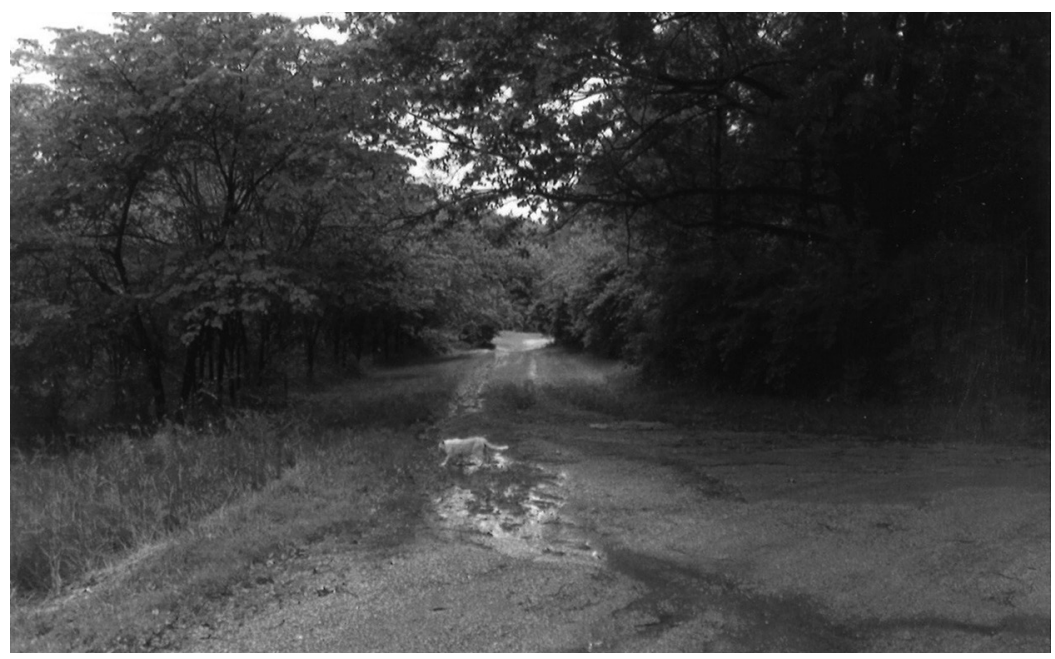

Figure 3. Old road leading into the Lincoln survey plat

who had recently purchased 40 adjoining acres to the south and a year earlier had married his cousin, Sarah Mitts. Interested in "homesteading," Joshua and Sarah paid $\$ 150$ for the 63 acres, possibly with a structure on it and a road leading into it. Of greater interest, the indenture for the sale of this parcel to Joshua and Sarah reflects the exact wording in the original survey as recorded by Lincoln, indicating the indenture was copied word for word from his survey. This indenture was drawn up in December, three months after the survey. However, the actual sale and transference of the surveyed property did not take place until February 9, 1837. Early Lincoln associate and Cantrall neighbor George Power, as justice of the peace, witnessed and signed this indenture. ${ }^{30}$

The early September weather proved to be a good time for surveying, except for the challenge of the land condition with high grass, brush, and briars. Lincoln packed his saddle bags with his axe, flags, plumb bob, chain, stakes, and Rittenhouse Vermier compass with its

30. Boyd, Family Maps of Sangamon County, 91, 96. The intent of this parcel passing to Joshua is the statement written in pencil on the survey, "William G. Cantrall and Deborah his wife to Joshua M. Cantrall"; see fn. 44. Indenture for the sale of this land by William G. Cantrall and Deborah, his wife, to Joshua M. Cantrill and Sarah, his wife, February 9, 1837, for 63 acres, Document \#14 in "The Cantrall Family Collection," Sangamon Valley Collection. (Lincoln's name and the listed chainmen were not included in this indenture copied from his survey.) 
long pole strapped to his saddle. He rode east from New Salem toward Athens and then southeast toward the Cantrall farm about fifteen miles. There is the probability that he may have gone to the Public Land Office in Springfield to study the records of the government surveys, taking note of the original survey field notes for Section 20, including the description of the land and the surveyor's posts. The original survey for dividing Township 17 into sections was done in June 1822. It described the land for prospective buyers as "Land level and rich, timber oak and hickory." There was water available with a creek, later called Cantrall Creek, running through the southeast quarter of Section 20, and a brook in the northeast quarter of the section tangent to the eastern edge of Lincoln's survey. ${ }^{31}$

Arriving on the Cantrall farm on September 5, 1834, Lincoln conferred with William on the intent of the survey. The two men may have gone by horseback to look over the general area of the intended survey. William offered two of his sons, Joshua (1810-1891) and Adam (1815-1882), to serve as Lincoln's chainmen. With his surveyor's notebook and pencil in hand, Lincoln simply "went at it" by making notations for drawing up the formal survey. ${ }^{32}$

In discussion with William, he located his starting point (Point A) by indicating a bearing tree, in this case a white oak, bearing south 60 degrees, west 33 links, a point that may have been marked by an earlier surveyor's "hedge stake." Joshua and Adam, one of them serving as chainman and the other as flagman, carried the chain west, perhaps following the previously surveyed line (Point B). From here

31. Lincoln's surveying equipment is on display in the museum at the New Salem State Historic Site. The task of the federal surveyors was "to locate Congressional Townships and stake off sections and quarter sections for settlers to pre-empt." From the field notes of the original surveyors, Lincoln could look for "bearing trees from which to locate and re-establish section corners." They also rated the land and noted streams and bottom lands. Baber, Compass and Chain, xvi-xvii, 157. (See fn. 33 for the government land survey for this section.)

32. "Any individual requesting a survey must employ his own chainmen subject to the approval of the surveyor. The surveyor is required by law to keep a well-bound book in which to record all surveys made by him, giving such information as the name of the persons whose land is surveyed and descriptive data of the survey ... The surveyor also preserves his field notes and retains copies of plats." Works Progress Administration, Inventory of the County Archives of Illinois (Chicago: WPA, 1939), No. 83:181. Guidance on how Lincoln may have proceeded with this survey was shared with the author in separate interviews on Feb. 13, 2019, with Duane Weiss, retired licensed land surveyor, and with Wayne C. Temple, retired Chief Deputy Director of the Illinois State Archives and an honorary member of the Illinois Professional Land Surveyors Association. 


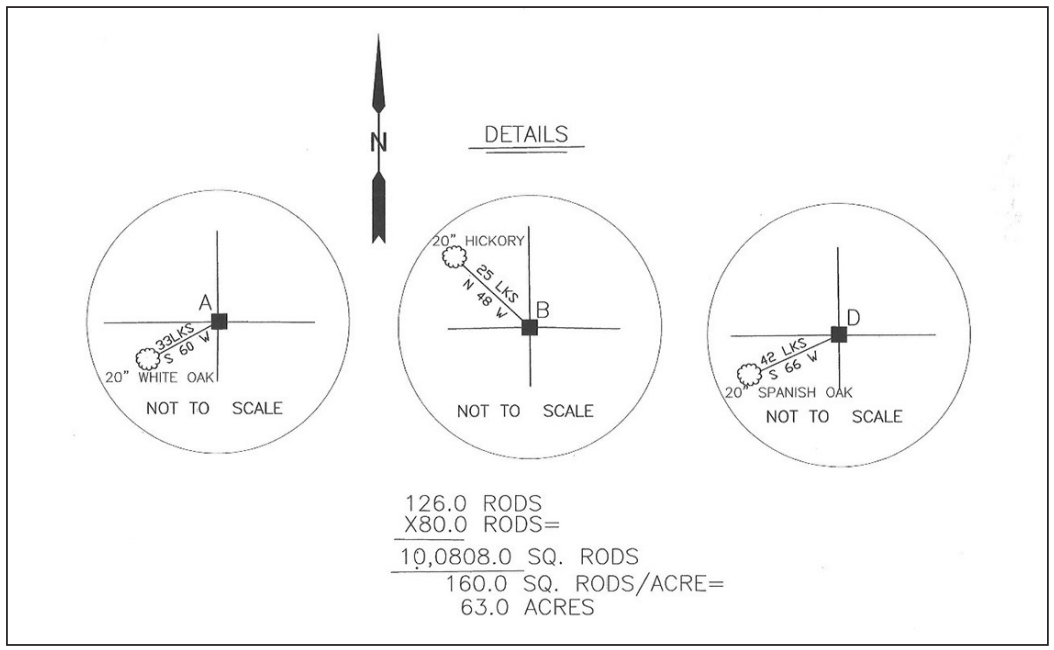

Figure 4. Detail drawing of the three bearing trees used by Lincoln in completing his survey

they went north to the mid-quarter section "line" (Point C), then east to the mid-point of the northeast quarter-section (Point D), then south to the starting point. As Lincoln walked the land, he recorded the chains and links and compass readings in his small notebook, calculating the math for drafting the final survey.

Completing his field notes, Lincoln may have gone into Cantrall's house, sat down at a table, and drafted the final survey in ink on a large ledger-size sheet of paper. Drafting the survey, he began with the words: "1834 Sep. 5 Surveyed for William G. Cantrill the following tract of land (to Wit)." He continued with the description:

Begining at the South East corner of the West half of the North East quarter of Section 20 in Township 17 of Range 5 West [of the Third Principal Meridian], at a White Oak, 20 inches in diameter bearing South 60 degrees West 33 Links [i.e., 21.78 feet] [Point A]

Thence West 31 chains \& 50 Links [2,079 feet] to a Hickory 20 inches [diameter] N 48 W. 25 Links [16.5 feet] [Point B]

Thence North 20 chains [1,320 feet] to a Stake [Point C]

Thence East 31 chains \& 50 Links [2,079 feet] to a Spanish Oak 20 inches [diameter bearing] S 66 [degrees] W 42- Links-[27.72 $\mathrm{ft}$.] [Point D] Thence South 20 chains [1,320 feet] to the begining. [Point A] 
Completing his survey, he concluded by recording Joshua and Adam as the chainmen and by signing with his usual authorized form: "J. Calhoun SSC [Surveyor for Sangamon County] By A. Lincoln." 33 At the bottom of this survey are two additional notations. One is a math division calculation dividing 10,080 by 160 . This is a surveyor's calculation that had to have been completed by Lincoln wherein he converts chains into rods to determine the total acreage of his survey. Using this conversion, one chain equals four rods, and one acre is equal to ten square chains. This surveyed parcel measures 31.5 chains by 20 chains. When converted into rods, it is 10,080 square rods (total area) divided by 160 square rods (one acre), yielding 63 acres. In lay terms, as can be seen, the tract is a rectangle about 2,079 feet by 1,320 feet. This is the only known survey with math calculations in Lincoln's hand. A second notation on the survey written later in pencil, perhaps by William, reads: "William G. Cantrall and Deborah his wife to Joshua M. Cantrall." 34

Lincoln surveyed this parcel and drafted it within a day's work. Handing the completed survey to William, Lincoln was paid according to the scale set by the legislature of $\$ 2.50$ for each quarter section and $\$ 2.00$ for travel expenses. Abiding in frontier hospitality, Lincoln most likely had a meal with the Cantralls, and may have spent the

33. For the original federal land survey for this Lincoln survey, see U.S. Surveyor General's Records for Illinois, "Federal Land Surveyor's Field Notes," Record Series 953-005, Illinois State Archives, Springfield, Vol. 122, June 23, 1822, pp. 226, 240. Lincoln's survey is drawn on a large sheet with a red line along both margins, similar to a ledger sheet. Dr. Wayne Temple noted to author, "Lincoln used various available paper to draft his surveys." Interview with author, Feb. 13, 2019. A transcription of the survey by Lincoln for William G. Cantrill is recorded in the Papers of Abraham Lincoln: Certificate of Survey for William G. Cantrill [1834-09-05] https:/ / papersofabrahamlincoln .org/document D302441, PAL Digital Library.

34. For an interpretation of the math calculation by Lincoln on this survey along with an understanding of early surveying, the author is indebted to Duane Weiss, who is deeply interested in Lincoln's practice as a surveyor. He offers the following interpretation of Lincoln's four rods per chain: "31.5 chains $x 4$ rods $=126$ rods

20.0 chains $\times 4$ rods $=80$ rods area $=$ length $\times$ width 126 rods $\times 80$ rods $=$ 10,080 square rods

one acre $=10$ square chains or 1 chain $(4$ rods $) \times 10$ chains ( 40 rods) or

1 acre $=160$ square rods

Therefore, 10,080 square rods (total area) divided by 160 square rods ( 1 acre) $=63.0$ acres.

According to Mr. Weiss, this had to be a surveyor's calculation to determine the number of acres surveyed. The pencil notation on the survey, conveying the surveyed parcel to Joshua M. Cantrall, is a later addition, evidenced by the spelling of 'Cantrall.' In conversation with the author on Feb. 13, 2019, Dr. Temple claims this pencil notation is Cantrall using this survey as a transfer of deed to his son Joshua. 
night with them, as was frequently his custom when surveying private property. He may have stayed over with a neighboring friend, such as George Power, about five miles north of the Cantrall farm, or returned to the Abells' near New Salem. ${ }^{35}$

Serving as a chainman, Joshua Cantrall established an early acquaintance with Lincoln. Three miles to the south of the Cantrall farm and survey was the farm of Archer G. Herndon, father of William H. Herndon. The Cantrall family used the law firm of Lincoln and Herndon. Years later in 1866 when it came time to write his father's final will, Joshua asked Herndon to draw it up. Upon his father's death on March 6, 1867, Joshua became the executor for the estate, probated by Herndon and Charles Zane. ${ }^{36}$ In that same year, Archer Herndon died, and William Herndon inherited from his father's estate the farm with the house along with more than 583 acres. Due to financial concerns, Herndon moved with his family to this farm in 1871, which he called Fairview for its wonderful vista overlooking the Sangamon River Valley. With this move, Herndon became a "neighbor" to the Cantralls. He and Jacob M. Cantrall, the son of Joshua, served together on the School Board for District No. 5 in Township 17; Herndon served as president from 1882-1884 and Jacob as secretary. Occasionally the board met at Herndon's farm house to discuss the routine business of hiring teachers, ordering equipment, and repairing school property. ${ }^{37}$ On this farm Herndon lived his final years, dying there in 1891.

What became of the land Lincoln surveyed for William G. Cantrall? Joshua and Sarah Cantrall retained ownership of the entire 63 acres from 1837 until 1882, when they conveyed 40 acres of it to their son

35. Pratt, Personal Finances, 18. There is no record of Lincoln's doing another survey in the area around this date. He most likely made his way back to New Salem. In a letter to Herndon, Feb. 15, 1867, Elizabeth Abell claims that Lincoln "stayed at our house on the bluff [near New Salem] when he was surveying all those Hills between us and Petersburg, our oldest boy carried the Chain for him when Lincoln would come in at night all ragged and scratch up with Bryers ..." Wilson and Davis, Herndon's Informants, 556-57.

36. Circuit Court Records for Sangamon County, Estate of William G. Cantrall, 1867, Case 1903, p. 352. William was buried in Cantrall Cemetery on land he had set aside for family burials, located off Route 29 , west at the green marker $8 \mathrm{~N}$. for 3 miles and a quarter mile through a field. The cemetery is in a field of timber, overgrown, with most of the stones fallen and buried. Also buried in this cemetery are Joshua M. and his son Jacob M.

37. "Record of Proceedings of Board of Directors for School District No. 5, T. 17, Sangamon County, April 16, 1881-April 19, 1884." (Book is owned by the author.) See also Gary L. Erickson, "The Last Years of William Henry Herndon," Journal of the Illinois State Historical Society 67:1 (Feb. 1974), 101-19. 
Jacob Mitts Cantrall..$^{38}$ It is worth noting further that after a few land transactions by extended family between 1885 and 1917, the descendants of William's brother Levi became the owners of a majority of this surveyed parcel. By 1919 Lucy Cantrall (1885-1959), Levi's greatgranddaughter, and her husband Earl D. Brown (1891-1972), owned about $85 \%$ of the Lincoln land survey along with additional acreage for a total of 119 acres, all once owned by William G. Cantrall at the time of Lincoln's 1834 survey. ${ }^{39}$ Earl and Lucy Brown lived with their three children, Eugene, Raymond, and Lillian Louise, in a house built about 1880 near the eastern edge of the survey. In this house their son Raymond Cantrall Brown was born in 1917. Growing up in this house, Raymond recalls that as a young man in 1941 he cut down four large old black walnut trees that must have stood on the land when Lincoln completed his survey. Raymond stored the walnut wood in the barn until around 1979 when he began using the wood to make furniture. From this black walnut he made the case in which the Illinois State Historical Library (now the Abraham Lincoln Presidential Library) displayed its copy of the Gettysburg Address, the Everett copy, written in Lincoln's hand; the case is no longer used for this purpose. ${ }^{40}$

The other 15 percent of this Lincoln survey that cuts into the south center of the original survey remained in the William Cantrall family, owned in 1914 by William's great-grandson Jacob Ernest Mitts Cantrall, called Ernie. He and his wife, Lillian E. Primm, lived in the old house on the south edge of the survey with its original log section built by Joshua, son of William. The Cantralls were similar to most early settlers in this region in building log homes of "white oak and black walnut," as stated in a letter mailed from New Salem on August 3,

38. Jacob Mitts Cantrall's first wife, Marian Tufts (1848-1879), died and he remarried to Martha Brown (1861-1898) in 1880, shortly prior to his purchase/inheritance of this additional land including most of the survey, on March 29, 1882. (The surveyed portion is described as part of SW 1/4 NE 1/4 Sec. 20 Twp. 17N 3rd P.M.) Indenture is document No. 9 in the Cantrall Family Collection, Sangamon Valley Collection.

39. Illustrated Atlas Map of Sangamon County, Illinois (Chicago: Brink, McCormick \& Co., 1874), 33. Plat Book of Sangamon County, Illinois (Chicago: Field Pub. Co., 1894), 55. Plat Book of Sangamon County (Springfield: The Sangamon County Abstract Co., 1914), 47. Atlas and Plat Book: Sangamon County, Illinois 1975 (Rockford, Ill.: Rockford Map Pub., 1975), 34. Land, Atlas, and Plat Book: Sangamon County, Illinois 2008 (Rockford, Ill.: Rockford Map Pub., 2008), 56. Cantrall Family Collection, Sangamon Valley Collection.

40. Interviews by author with Raymond Cantrall Brown (1917-2018) on May 20, 2017, Feb. 15, 2018, and April 4, 2018. Mr. Brown had a fascination with the history of the Cantralls. He grew up in the house that stood on the land Lincoln surveyed, yet was not aware that Lincoln had surveyed the land. Some of the four black walnut trees from which he made furniture were, he claimed, three feet in circumference. "Cantrall Man Looks Back Over 101 Years," State Journal-Register (Springfield), Mar. 11, 2018: p. 9. 
1834, written by Charles J. F. Clarke to his family back in New Hampshire. Clarke went on to explain the situation of early settlers like the Cantralls: "I have been requested by all those that I have rec'd letters from to write what the people live in, what they live on ... I should judge nine tenths of them live in log houses and cabins the other tenth in brick or framed houses. The people generally have large farms and have not thought so much of fine buildings as they have of adding land to land ... Many a rich farmer lives in a house not half so good as your old hog pens and not any larger." ${ }^{\prime 11}$ The original log portion of this home, built by Joshua, is buried in the present structure, which has resulted in many additions through the years, including a second story. Here Ernie and Lillian Cantrall, the last Cantralls to live in the house, raised three children, Harold (b. 1905), LeRoy (called George, b. 1907), and Lillian (b. 1909). A granddaughter of Ernie and Lillian, Dorothy Rose Wright, recalled that only an orchard separated the home of her grandfather Ernie (a descendant of William G.) from the house of Earl Brown (a descendant of Levi)—all on the land Lincoln surveyed. ${ }^{42}$

Between 1971 and 1973 the children of Ernie and Lillian, as well as the children of Earl and Lucy, sold their land and buildings to Frank and Cheryl Moscardelli, who purchased it under the name Pleasant Nursery. This purchase included the entire 63-acre survey. As of 2020 the Moscardellis remain the owners of about 185 acres of former Cantrall land settled from the 1820s; and they reside in the old Ernie Cantrall home with its log structure section beneath the siding. The old Earl Brown home on the survey site was abandoned and razed in

41. Charles R. Clarke, "Sketch of Charles James Fox Clarke with Letters to His Mother," Journal of the Illinois State Historical Society 22:4 (Jan. 1930), 563. This collection of letters by a migrant to his family near Northwood, New Hampshire, is in the Abraham Lincoln Presidential Library. Clarke came to Illinois in the winter of 1833-34 and settled in Rock Creek Precinct, adjacent to New Salem. He came with a relative, Matthew S. Marsh, who is noted for his commentary in a letter to his brother on Lincoln's being careless as Postmaster of New Salem, "leaving the office open and unattended." The collection of letters, particularly that of Aug. 3, 1834, written a month prior to the Cantrall survey, is very revealing of life in New Salem.

42. Plat Book of Sangamon County, Illinois, 1914, 47. Author's interview with present owners on May 20,2017, mentioned an original log structure with a seven-foot ceiling within their home used as a bedroom. Phone interview with Dorothy Rose Wright whose mother grew up in this house with her parents, Ernie and Lillian Cantrall, mentioned an orchard that separated the two Cantrall homes. Built by Joshua M. Cantrall, this log home may have been on the site at the time of the Lincoln survey, though such a structure existing is unlikely. There is a family tradition that the log structure was moved there from another site on the Cantrall property. Interview with Raymond Cantrall Brown, May 20, 2017. 


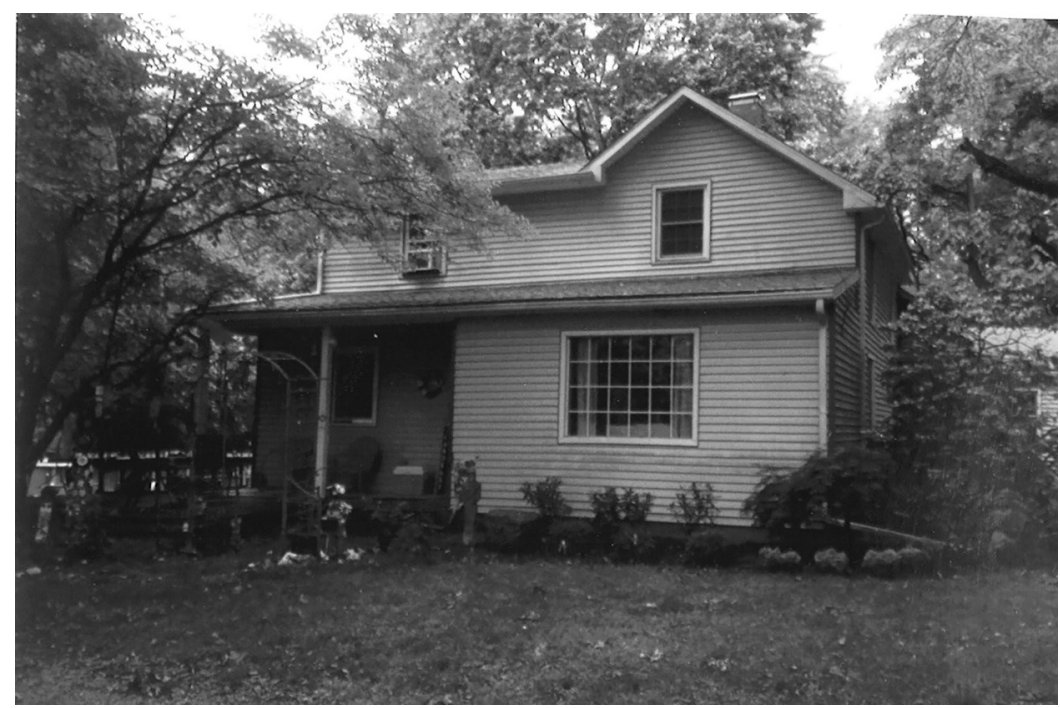

Figure 5. Present residence of Frank and Cheryl Moscardelli with siding over the original log portion built by Joshua Cantrall

about 1979. Frank, who grows some nursery stock on the land, recalls that when he purchased it, much of the land consisted of crops and pasture. An old road with only tracks through an opening leads into the Lincoln survey site, parallel but slightly to the north of the present road leading from the highway to the Moscardelli house. No visible Lincoln survey markers remain on the site, with much of the land having returned to a natural state. ${ }^{43}$

\section{Postscript}

There has been very little published on Lincoln's life as a surveyor except for Adin Baber's 1968 book. Biographers have usually covered

43. The author, along with retired surveyor Duane Weiss, on May 20, 2017, visited the survey location. It is off Rte. 29 about 8 miles north of Springfield, officially 7357 N. State Route 29, Cantrall, Ill. The land is titled in the name of the nursery, Pleasant Nursery. The old barn on the surveyed plot is a later addition, built around 1920. In the distance, in an open field, there are the remains of a large white oak, struck by lightning in about 2008. Raymond Brown claimed that it served as a "witness tree," though if dated back to the time of Lincoln's survey, it had to have been a sapling. Eight feet from the old white oak is a large rock used by surveyors. Straight west of this rock is another rock ... perhaps Lincoln or the federal land surveyors made use of them as markers. This observation was shared by Raymond C. Brown in an interview, April 4, 2018. 
this subject in a few pages with similar content and references. When a previously unknown survey is uncovered, it warrants a search into how it adds to the Lincoln narrative. This survey for William Cantrall is not only about the dry sectional numbers on a drafting page but about the Cantralls, their lives and movement with the life of Lincoln. For Lincoln surveying provided income, "procured bread and kept soul and body together." His diligent self-tutored course and field work in surveying were also a test of his practical abilities in math, science, logic, geography, and manipulating instruments in a personal campaign to better himself. Frontier Illinois involved land and the settlement of land. Surveying involved working the land, and Lincoln desired to break with the farm labor of his father to find a new relationship with the land. Surveying helped expand his community beyond New Salem toward Springfield with new opportunities in law and politics.

As a struggling young man trying to find direction, Lincoln took up surveying to help pay bills. In contrast, 70 years later, as a wealthy older man, Robert Todd Lincoln took up surveying as a hobby at his summer estate, Hildene, built for his retirement near Manchester, Vermont. For the observatory he built on the grounds, "Robert selected and surveyed the site himself as well as personally surveying his entire acreage, including all the routes for building fences and roads for the property." 44 Lincoln did surveying out of necessity and his son did surveying out of passion.

44. Jason Emerson, Giant in the Shadows: The Life of Robert T. Lincoln (Carbondale, Ill.: Southern Illinois University Press, 2012), 361-62. Books owned by Robert T. Lincoln on surveying are in the author's personal collection. 